\title{
Bidens pilosa L. (Asteraceae): traditional use in a community of southern Brazil
}

BORGES, C.C. ${ }^{1}$; MATOS, T. F. ${ }^{1}$; MOREIRA, J.2; ROSSATO, A.E. ${ }^{2}$; ZANETTE, V. C..$^{3}$ AMARAL, P. A..$^{* * 1,2}$ Acadêmico(a) do Curso de Farmácia da Universidade do Extremo Sul Catarinense (UNESC). ${ }^{2}$ Grupo de Extensão e Pesquisa em Plantas Medicinais - GEPPLAM (UNESC). ${ }^{2,3}$ Herbário Pe. Dr. Raulino Reitz, Universidade do Extremo Sul Catarinense (UNESC). 1,2,3UNESC, Av. Universitária n 1105, Bairro: Universitário, CEP: 88806-000, Criciúma - SC, Brasil. *paa@unesc.net

RESUMO: Bidens pilosa Linn (Asteraceae): Uso tradicional em uma comunidade do Sul do Brasil. O emprego correto de plantas para fins terapêuticos pela população requer o uso daquelas selecionadas por sua eficácia e segurança, com base na tradição popular e/ ou cientificamente validadas como medicinais. Bidens pilosa L. é uma espécie que ocorre amplamente em regiões tropicais sendo conhecida no Brasil pelo nome popular "picãopreto". Quatro agentes da pastoral da Saúde foram identificadas na região de Criciúma/ SC por possuírem maiores informações de cunho popular sobre Bidens pilosa. A pesquisa ocorreu por meio de entrevista, onde foram compiladas informações sobre o conhecimento do "picão-preto", manuseio, farmacógeno, proporção farmacógeno/ solvente, técnica de preparo, formas de uso/posologia, indicações e restrições de uso. A forma farmacêutica utilizada variou significativamente, assim como a posologia. A análise de informações coletadas mostra a ação antiinflamatória como principal indicação terapêutica.

Palavras-chave : planta medicinal, Bidens pilosa L., conhecimento popular, atividade antiinflamatória.

ABSTRACT: The correct use of plants for therapeutic purposes requires selection of those showing efficacy and safety based on the popular tradition and/or scientific validation. Bidens pilosa $\mathrm{L}$. is a species that widely occurs in tropical regions and is known in Brazil as "picãopreto". Four agents from the Health Pastoral Service were identified in the region of Criciuma, Santa Catarina State, for their popular knowledge of Bidens pilosa. The study was conducted by means of interview which provided data concerning the knowledge of "picão preto", handling, used plant part, plant/solvent proportion, preparation methods, administration route/dosage, indication and restrictions. The pharmaceutical form, as well as the posology, was significantly variable. Analysis of the collected data showed anti-inflammatory action as the main therapeutic indication.

Key words: medicinal plant, Bidens pilosa L., popular knowledge, anti-inflammatory action.

\section{INTRODUCTION}

Over the centuries, natural products, especially from plants, have been the basis for the treatment of different diseases, and the knowledge of plants as medical and health references is still the main therapeutic source for a large number of communities and ethnic groups (Amorozo, 1996; Di Stasi, 1996; Corrêa et al., 2002; Maciel et al., 2002; Vilegas et al., 2007).

The correct popular use of plants for therapeutic purposes requires the selection of those showing efficacy and safety based on tradition and/or scientific validation as medicinal. An ethnobotanical study is one of many strategies to be considered for the investigation of biological activities in medicinal plants. It consists in collecting information from local communities or specific people who use plants for medicinal purpose, together with information from pharmacological and phytochemical studies performed in specialized laboratories (Elisabetsky, 1986, 1987; Elisabetsky \& Costa-Campos, 1996).

Bidens pilosa L. (Asteraceae), popularly known as "picão-preto", is a widely occurring plant species that has been used by the community of Criciúma (State of Santa Catarina/Brazil) and studied by Universidade do Extremo Sul Catarinense (UNESC). This species has several

Recebido para publicação em 24/10/2011

Aceito para publicação em 02/07/2012

Rev. Bras. PI. Med., Botucatu, v.15, n.1, p.34-40, 2013. 
traditional therapeutic indications and is especially recommended for its anti-inflammatory action. Bidens pilosa is a small plant species originated from the South America and currently found in many tropical and subtropical countries. It is an annual, erect, ruderal, invasive herb with a quadrangular stem that grows up to $1.5 \mathrm{~m}$ height, presenting branches from the base and yellow floral capitulum of 5-15 mm in diameter (Corrêa, 1984; Silva et al, 2011).

In fact, about $25 \%$ of the medicines currently prescribed worldwide are higher-plant-derived products, such as quinine, digoxin, morphine and paclitaxel. Nowadays, the growing interest in medicinal plants can be justified by these classic findings, along with a lack of access to essential drugs for a large part of the world population (Rates, 2000; Phillipson, 2007)

Ethnopharmacological studies performed in Cuba, the Bahamas, Amazonia and southern Brazil have shown that Bidens pilosa has been used to treat a variety of illnesses including inflammation and tumors (Pereira et al, 1999; Valdés \& Rego, 2001; Franco \& Fontana, 2004). Virtually, all plant parts can be used in traditional medicinal preparations which can be administered as a drink and/or topical application (Corrêa, 1984). Phytochemical evaluation of Bidens pilosa revealed a rich phytochemical constitution. The main compounds that have been isolated from the plant are acetylenic and flavonoid compounds (Brandão et al., 1997). Other studies from plants collected in Egypt have reported the presence of â-amyrin, â-phytosterin, esculetin, â-sitosterol glycoside and lupeol (Sarg et al., 1991). More recently, terpenes, flavonoids, aurone glycosides and the chalcones butein and okanin have been isolated from the plant (Valdés \& Rego, 2001; Silva et al, 2011).

In South America, as well as in other parts of the globe, religious organizations can act directly for the population well-being and health, providing social and preventive health services for specific groups of people. In Brazil, the Catholic Church represents an influential organization and its organized segments like the Health Pastoral (Pastoral da Saude) can play an important role for health promotion in small communities (IBGE, 2000; DeHaven et al., 2004; Murray et al., 2011).

Bidens pilosa was included in the official list of medicinal plants with potential for herbal use by the public health system and represents, from an economic standpoint, a valuable option as remedy for the community of Criciúma/Santa Catarina. On this basis, the aim of the present study is to analyze information from four informers of the Catholic Church's Health Pastoral on the current use of Bidens pilosa in traditional therapeutic preparations.

\section{MATERIALS AND METHODS}

\section{Survey}

Bidens pilosa data were collected through open and closed questions/interviews with the informers. Criteria used for the selection of informers were availability and interest to take part in the study (Di Stasi, 1996). Initially, thirty agents from the Health Pastoral proposed to participate in the study. From this number, only four informers were chosen for this survey, according to their perceived knowledge of Bidens pilosa therapeutic uses. These four informers represent an average population of 700 people with whom they interact directly during the development of Pastoral activities.

All informers gave written, informed consent to participate in this survey, which was approved by the Ethics Committee of UNESC (Universidade do Extremo Sul Catarinense) under the number 245/2010.

\section{Botanical Material}

Leaves from Bidens pilosa L. were collected in March 2010, at Grão Pará, Santa Catarina State. The collection site is at $28^{\circ} 14^{\prime} 00.0^{\prime \prime} S$ and 49017'58.7'W. Voucher specimens were identified and deposited in the Herbarium Padre Dr. Raulino Reitz of UNESC-Criciúma under the number CRI-7613. Given that the leaves are the part predominantly used by the local population, Bidens pilosa leaves were specifically chosen to be studied herein.

\section{RESULTS}

The four informers selected to take part in the present study were classified by letters A-D. All selected informers reported acquiring their first knowledge of Bidens pilosa L. through oral transmission passed down from their parents or grandparents. The vernacular name that was unanimously cited for the species was "picão-preto"; only informer A reported two other vernacular names for the plant, "pica-pica" and "amor de mulher". As to growing, all informers reported that Bidens pilosa grows spontaneously. Collection generally occurs in neighborhood gardens and the chosen species are always in good condition, free from extraneous matter and physical damage, and not close to roads or contaminated areas. According to Corrêa (1998) and Martins (2000), these practices are necessary to insure the quality of preparation.

Interviewees described Bidens pilosa as a plant with dark-green stem and green leaves, light smell, presenting no latex or mucilage. Three informers cited the presence of flowers, but only informer $\mathrm{C}$ reported the opposite, probably due to $\mathrm{a}$ 
vague examination of the plant. All four interviewees reported the absence of fruits for this species in opposition to literature data, describing Bidens pilosa with yellow inflorescence and black fruits. It is possible that the popular misconception of fruits as obligate edible and fleshy botanical structures accounted for the lack of fruit description by the informers (Martins, 2000; Corrêa et al., 2003; Silva Junior, 2006).

Concerning the plant part used in therapeutic preparations of Bidens pilosa, interviewees A and B reported to use the entire plant, $D$ reported to use leaves and flowers and $\mathrm{C}$ reported to use all plant parts, even the roots. In fact, all plant parts can be used for therapeutic purposes (Simões, 1989; Corrêa et al., 2003; Silva Junior, 2006).

Informers described to collect the plant until 10 a.m. or after 4 p.m., avoiding hours with blazing sunlight which can shrivel the plant. Corrêa (1998) says that morning is the best time for collection, after dew evaporation, or close to sunset. On cloudy and dry days, plants can be collected at any time. Once asked on how they knew the correct way and time to collect the plant, informers said that they had learned during lectures on medicinal plants at UNESC-Criciúma.

All interviewees reported to use only the fresh plant. According to Martins (2000), the use of fresh medicinal plants insures the constancy of active plant constituents. Good drying methods can also insure the stability of plant constituents when the fresh use is not possible. Informer A reported to have previously used air-dried leaves of Bidens pilosa, which were stored for future use. To produce satisfactory results, air-drying processes must be conducted in a cool, dark, dry and well-ventilated room insuring the constancy of plant compounds (Corrêa, 1998).

Decoction, infusion and tincture were the medicinal preparations most frequently reported and used by the informers (Table 1). According to interviewees, the choice of preparation depends directly on the therapeutic indication and is based on cultural and social context.

Martins (2000) states that Bidens pilosa

TABLE 1. Preparation and frequency of use

\begin{tabular}{lc}
\hline Preparation & $\begin{array}{c}\mathbf{N}^{\circ} \text { informers using } \\
\text { the preparation }\end{array}$ \\
\hline Infusion & 02 \\
Decoction & 04 \\
Tincture & 03 \\
Syrup & 01 \\
Medicinal wine & 01 \\
Juice & 01 \\
Poultice & 02 \\
\hline
\end{tabular}

infusion can be prepared by using $1 / 2$ cup of plant material in $1 / 2$ liter of water and that oral adult dosage is 1 cup 6 times a day. Informer $C$ was the only one to report information close to this reference (Table 2). Informers reported to use the infusion few minutes after preparation, which is in accordance with methods described by Simões (1989).

Informer C also reported using Bidens pilosa to treat diabetes. Recent studies showed the anti-hyperglycemic properties of Bidens pilosa, the extracts of which decreased glucose and increased insulin levels in the serum of mice, corroborating the above-mentioned indication (Hsu et al, 2008; Chien et al, 2009).

According to Prista (1991), stem bark and roots are the plant parts indicated to prepare a decoction of Bidens pilosa. Stem bark can only be obtained following plant dehydration. As shown in Table 03, the plant parts used by the informers are not completely in accordance with literature data. Indeed, interviewees reported using the entire plant or the aerial part to prepare decoctions.

Decoction methods reported by interviewees diverged from the conventional methods presented in the literature. The variations in plant material and solvent quantities used by the informers are difficult to consider and therefore to compare with data in the literature.

According to Corrêa (2003), root, rhizome, stem and bark can be used in decoctions. The plant material should be immersed in water, boiled for 10 to 15 minutes and then filtered. As shown in Table 3, the boiling time reported by the informers was inferior to the one indicated in the literature.

Informers $A$ and $C$ reported that decoction of Bidens pilosa should be rapidly used (around 15 minutes) after preparation, whereas informers $B$ and $D$ reported that the decoction may be consumed within a 24-hour period. However, medicinal preparations like decoction should be consumed soon after preparation to guarantee the stability of compounds and the therapeutic effect (Prista et al., 1990).

Interviewees $\mathrm{B}$ and $\mathrm{C}$ indicated Bidens pilosa decoction to treat gastrointestinal complications. Recent studies showed the protective effect of methylene chloride extract of Bidens pilosa leaves on various gastric ulcer models in rats, corroborating the reported therapeutic application (Tan, Dimo \& Dongo, 2000).

As stated in Brazilian Pharmacopeia, tincture is a preparation made with dried plants at the proportion of 1:5 or 1:10 plant material/solvent. As shown in Table 4, the reported preparations are similar to the methods described in "Farmacopéia Brasileira II" (Brasil, 1959), in which plant material macerates for 10 days in a sealed container, at room temperature, with periodical homogenization. 
Informer $\mathrm{C}$ reported that plant material can macerate for 8 days instead of 10 , which is also correct according to Corrêa (2003).

The preparation juice described by informer $A$, as shown in Table 5 , is in accordance with the literature (Corrêa et al., 2003). A study showing the anti-inflammatory effects of the methanolic extract, as well as of polyacetylenes isolated from Bidens pilosa, corroborates the therapeutic indications mentioned by the informer, which are pain and inflammation (Pereira et al., 1999).

The poultice shown in Table 6 has distinct preparation methods according to each informer, although both are correct according to the conventional preparation methods described by Martins et al. (2000) and Corrêa et al. (2003).

TABLE 2. Infusion

\begin{tabular}{|c|c|c|c|c|c|c|c|c|}
\hline Informer & $\begin{array}{l}\text { Plant } \\
\text { part }\end{array}$ & $\begin{array}{l}\text { Plant/solvent } \\
\text { Proportion }\end{array}$ & $\begin{array}{l}\text { Plant } \\
\text { state }\end{array}$ & Preparation & $\begin{array}{c}\text { Claimed } \\
\text { medicinal use(s) }\end{array}$ & $\begin{array}{l}\text { Mode of } \\
\text { use }\end{array}$ & Dosage & $\begin{array}{l}\text { Restrictions } \\
\text { of use }\end{array}$ \\
\hline \multirow{2}{*}{$\begin{array}{c}\text { Informer } \\
\text { A }\end{array}$} & \multirow{2}{*}{$\begin{array}{l}\text { Aerial } \\
\text { parts } \\
\text { (stem, } \\
\text { leaves) }\end{array}$} & \multirow{2}{*}{$\begin{array}{l}20 \mathrm{~g} \text { of fresh } \\
\text { plant in } 1 \text { liter } \\
\text { of water }\end{array}$} & \multirow{2}{*}{ Fresh } & \multirow{2}{*}{$\begin{array}{l}\text { In a glass, add boiling } \\
\text { water over shredded } \\
\text { plant material, let } \\
\text { infuse for } 6 \text { minutes, } \\
\text { filter and drink rapidly } \\
\text { while warm. Shelf-life } \\
\text { of few minutes }\end{array}$} & $\begin{array}{l}\text { Bladder, kidney } \\
\text { and urinary tract } \\
\text { infections, hepatitis }\end{array}$ & Oral & $\begin{array}{l}\text { Adults only: } \\
1 \text { cup } 3 \text { times } \\
\text { a day }\end{array}$ & $\begin{array}{c}\text { Not } \\
\text { mentioned }\end{array}$ \\
\hline & & & & & $\begin{array}{l}\text { Varicose veins, } \\
\text { phlebitis and skin } \\
\text { eruptions }\end{array}$ & Topical & $\begin{array}{l}\text { At least } 3 \\
\text { times a day }\end{array}$ & $\begin{array}{c}\text { Not } \\
\text { mentioned }\end{array}$ \\
\hline \multirow[t]{2}{*}{$\begin{array}{l}\text { Informer } \\
\text { C }\end{array}$} & \multirow[t]{2}{*}{$\begin{array}{l}\text { Entire } \\
\text { plant }\end{array}$} & \multirow{2}{*}{$\begin{array}{l}1 / 2 \text { tbsp. of plant } \\
\text { in } 1 / 4 \text { liter of } \\
\text { water }\end{array}$} & \multirow[t]{2}{*}{ Fresh } & \multirow{2}{*}{$\begin{array}{l}\text { In a glass, add boiling } \\
\text { water over shredded } \\
\text { plant material, let } \\
\text { infuse for } 3 \text { minutes, } \\
\text { percolate and drink it } \\
\text { hot within } 15 \text { minutes }\end{array}$} & $\begin{array}{c}\text { Cough, sore } \\
\text { throat, stomach } \\
\text { pain, diabetes and } \\
\text { hepatitis }\end{array}$ & Oral & $\begin{array}{c}\text { Adults only: } \\
1 \text { cup twice } \\
\text { a day }\end{array}$ & $\begin{array}{c}\text { Not } \\
\text { mentioned }\end{array}$ \\
\hline & & & & & Wound healing & Topical & $\begin{array}{l}\text { Clean the } \\
\text { wound using } \\
\text { the infusion } \\
\text { once a day }\end{array}$ & $\begin{array}{c}\text { Not } \\
\text { mentioned }\end{array}$ \\
\hline
\end{tabular}

TABLE 3. Decoction

\begin{tabular}{|c|c|c|c|c|c|c|c|c|}
\hline Informer & $\begin{array}{l}\text { Plant } \\
\text { part }\end{array}$ & $\begin{array}{l}\text { Plant/ } \\
\text { solvent } \\
\text { Proportion }\end{array}$ & $\begin{array}{l}\text { Plant } \\
\text { state }\end{array}$ & Preparation & $\begin{array}{l}\text { Claimed } \\
\text { medicinal } \\
\text { use(s) }\end{array}$ & $\begin{array}{l}\text { Mode } \\
\text { of use }\end{array}$ & Dosage & $\begin{array}{c}\text { Restrictions } \\
\text { of use }\end{array}$ \\
\hline $\begin{array}{c}\text { Informer } \\
\text { A }\end{array}$ & $\begin{array}{c}\text { Aerial } \\
\text { parts } \\
\text { (stem, } \\
\text { leaves) }\end{array}$ & $\begin{array}{l}20 \mathrm{~g} \text { of plant } \\
\text { in } 1 \text { liter of } \\
\text { water }\end{array}$ & Fresh & $\begin{array}{l}\text { Boil the water in a glass or } \\
\text { enameled saucepan, add plant } \\
\text { material, shut and let it boil for } \\
5 \text { more minutes and then filter. } \\
\text { Shelf-life of a few minutes }\end{array}$ & $\begin{array}{l}\text { Bladder, kidney } \\
\text { and urinary } \\
\text { tract infections, } \\
\text { hepatitis }\end{array}$ & Oral & $\begin{array}{l}\text { Adults only: } 1 \\
\text { cup } 3 \text { times a } \\
\text { day }\end{array}$ & $\begin{array}{c}\text { Not } \\
\text { mentioned }\end{array}$ \\
\hline \multirow[t]{2}{*}{$\begin{array}{c}\text { Informer } \\
\text { B }\end{array}$} & \multirow[t]{2}{*}{$\begin{array}{l}\text { Aerial } \\
\text { parts } \\
\text { (flowers, } \\
\text { buds) }\end{array}$} & \multirow[t]{2}{*}{$\begin{array}{l}1 \text { cup of plant } \\
\text { in } 1 / 2 \text { liter of } \\
\text { water }\end{array}$} & \multirow[t]{2}{*}{ Fresh } & \multirow{2}{*}{$\begin{array}{l}\text { In a steel or enameled container } \\
\text { add the water } \\
\text { and plant material. Shut } \\
\text { and boil for } 5 \text { minutes. Filter } \\
\text { into a glass container. } \\
\text { Shelf-life of } 24 \text { hours. }\end{array}$} & $\begin{array}{l}\text { Bladder and } \\
\text { kidney infections, } \\
\text { rheumatic } \\
\text { disease, stomach } \\
\text { pain, sore throat }\end{array}$ & Oral & $\begin{array}{l}\text { Adults only: } 1 \\
\text { cup } 3 \text { times a } \\
\text { day }\end{array}$ & $\begin{array}{c}\text { Not } \\
\text { mentioned }\end{array}$ \\
\hline & & & & & Wound healing & Topical & 3 times a day & Not mentioned \\
\hline \multirow[t]{2}{*}{$\begin{array}{l}\text { Informer } \\
\text { C }\end{array}$} & \multirow[t]{2}{*}{$\begin{array}{l}\text { Entire } \\
\text { plant }\end{array}$} & \multirow[t]{2}{*}{$\begin{array}{l}2 \text { tbsp. in } 2 \\
\text { glasses of } \\
\text { water }\end{array}$} & \multirow{2}{*}{ Fresh } & \multirow{2}{*}{$\begin{array}{c}\text { Boil the water and plant } \\
\text { material in a shut stainless } \\
\text { steel container for } 3 \text { minutes. } \\
\text { Filter the decoction to a glass } \\
\text { container. Shelf-life of } 15 \\
\text { minutes }\end{array}$} & $\begin{array}{c}\text { Cough, sore } \\
\text { throat, stomach } \\
\text { pain, diabetes and } \\
\text { hepatitis }\end{array}$ & Oral & $\begin{array}{l}\text { Adults only: } 1 \\
\text { cup twice a day } \\
\text { Clean the }\end{array}$ & $\begin{array}{c}\text { Not } \\
\text { mentioned }\end{array}$ \\
\hline & & & & & Wound healing & Topical & $\begin{array}{l}\text { wound using the } \\
\text { decoction once } \\
\text { a day }\end{array}$ & $\begin{array}{c}\text { Not } \\
\text { mentioned }\end{array}$ \\
\hline \multirow{2}{*}{$\begin{array}{l}\text { Informer } \\
\text { D }\end{array}$} & Flowers & $\begin{array}{l}\text { A handful of } \\
\text { flowers in } 1 \\
\text { liter of water }\end{array}$ & Fresh & $\begin{array}{l}\text { Boil the water and plant material } \\
\text { in an enameled container for } \\
2 \text { minutes. Filter to a glass } \\
\text { container. Shelf-life } 24 \text { hours }\end{array}$ & Uterine cervicitis & Oral & $\begin{array}{c}1 \text { liter a day for } \\
3 \text { months }\end{array}$ & $\begin{array}{c}\text { Not } \\
\text { mentioned }\end{array}$ \\
\hline & $\begin{array}{l}\text { Entire } \\
\text { plant }\end{array}$ & $\begin{array}{c}\text { An entire } \\
\text { individual } \\
\text { plant in } 1 / 2 \text { liter } \\
\text { of water }\end{array}$ & Fresh & $\begin{array}{l}\text { Boil the water and plant material } \\
\text { in an enameled container for } 5 \\
\text { minutes. Percolate to a glass } \\
\text { container. Shelf-life of } 24 \text { hours }\end{array}$ & $\begin{array}{l}\text { Bladder and } \\
\text { urinary tract } \\
\text { infections }\end{array}$ & Oral & $\begin{array}{l}1 \text { cup } 3 \text { times a } \\
\text { day for } 10 \text { days }\end{array}$ & $\begin{array}{c}\text { Not } \\
\text { mentioned }\end{array}$ \\
\hline
\end{tabular}

Rev. Bras. PI. Med., Botucatu, v.15, n.1, p.34-40, 2013. 
TABLE 4. Tincture

\begin{tabular}{|c|c|c|c|c|c|c|c|c|}
\hline Informer & $\begin{array}{l}\text { Plant } \\
\text { part }\end{array}$ & $\begin{array}{l}\text { Plant/solvent } \\
\text { Proportion }\end{array}$ & $\begin{array}{l}\text { Plant } \\
\text { state }\end{array}$ & Preparation & $\begin{array}{c}\text { Claimed } \\
\text { medicinal use(s) }\end{array}$ & $\begin{array}{l}\text { Mode of } \\
\text { use }\end{array}$ & Dosage & $\begin{array}{l}\text { Restrictions } \\
\text { of use }\end{array}$ \\
\hline $\begin{array}{c}\text { Informer } \\
\text { A }\end{array}$ & $\begin{array}{l}\text { Entire } \\
\text { plant }\end{array}$ & $\begin{array}{l}40 \mathrm{~g} \text { of shredded } \\
\text { plant in } 1 / 2 \text { liter of } \\
\text { grain alcohol }\end{array}$ & Fresh & $\begin{array}{c}\text { Let the plant } \\
\text { material macerate } \\
\text { for a } 10- \\
\text { day period at room } \\
\text { temperature. Shelf- } \\
\text { life of } 1 \text { year }\end{array}$ & $\begin{array}{l}\text { Bladder, kidney } \\
\text { and urinary tract } \\
\text { infections }\end{array}$ & Oral & $\begin{array}{c}8 \text { drops from the } \\
\text { tincture in } 125 \mathrm{ml} \\
\text { of water } 3 \text { times } \\
\text { a day }\end{array}$ & $\begin{array}{c}\text { Not } \\
\text { mentioned }\end{array}$ \\
\hline $\begin{array}{l}\text { Informer } \\
\text { B }\end{array}$ & $\begin{array}{c}\text { Aerial } \\
\text { parts } \\
\text { (flowers, } \\
\text { buds) }\end{array}$ & $\begin{array}{l}\text { In a glass canning jar } \\
\text { add approximately } 450 \\
\text { g of shredded plant, } \\
\text { add grain alcohol or } \\
\text { pure cachaça (sugar- } \\
\text { cane alcohol) until fully } \\
\text { immersed }\end{array}$ & Fresh & $\begin{array}{l}\text { Let the plant } \\
\text { material macerate } \\
\text { for } 10-15 \text { days. } \\
\text { Shelf-life of } 1 \text { year }\end{array}$ & $\begin{array}{l}\text { Bladder, kidney } \\
\text { and urinary tract } \\
\text { infections }\end{array}$ & Oral & $\begin{array}{c}20 \text { drops from the } \\
\text { tincture in } 1 / 2 \text { cup } \\
\text { of water } 2-3 \text { times } \\
\text { a day }\end{array}$ & $\begin{array}{c}\text { Not } \\
\text { mentioned }\end{array}$ \\
\hline \multirow[t]{2}{*}{$\begin{array}{l}\text { Informer } \\
\text { C }\end{array}$} & \multirow[t]{2}{*}{$\begin{array}{l}\text { Entire } \\
\text { plant }\end{array}$} & \multirow{2}{*}{$\begin{array}{c}1 \text { cup of } \\
\text { chopped plant } \\
\text { material in } 1 \text { liter } \\
\text { of grain alcohol }\end{array}$} & \multirow[t]{2}{*}{ Fresh } & \multirow{2}{*}{$\begin{array}{l}\text { Let the preparation } \\
\text { macerate in a dark } \\
\text { glass container at } \\
\text { room temperature } \\
\text { for } 8 \text { days. Shelf- } \\
\text { life of } 1 \text { year }\end{array}$} & $\begin{array}{c}\text { Bladder and } \\
\text { kidney infections, } \\
\text { cholecystitis, cough, } \\
\text { bronchitis and } \\
\text { rheumatic disease }\end{array}$ & Oral & $\begin{array}{l}15 \text { drops from the } \\
\text { tincture in } 1 \text { cup } \\
\text { of water twice a } \\
\text { dayObs. Use during } \\
1 \text { week, and after a } \\
4 \text { day interval use it } \\
\text { again for } 1 \text { week }\end{array}$ & $\begin{array}{c}\text { Not } \\
\text { mentioned }\end{array}$ \\
\hline & & & & & $\begin{array}{l}\text { Muscular pain and } \\
\text { rheumatic disease }\end{array}$ & Topical & $\begin{array}{l}\text { Apply over the } \\
\text { skin twice a day }\end{array}$ & $\begin{array}{c}\text { Not } \\
\text { mentioned }\end{array}$ \\
\hline
\end{tabular}

TABLE 5. Juice

\begin{tabular}{|c|c|c|c|c|c|c|c|c|}
\hline Informer & $\begin{array}{l}\text { Plant } \\
\text { part }\end{array}$ & $\begin{array}{c}\text { Plant/solvent } \\
\text { Proportion }\end{array}$ & $\begin{array}{l}\text { Plant } \\
\text { state }\end{array}$ & Preparation & $\begin{array}{c}\text { Claimed } \\
\text { medicinal use(s) }\end{array}$ & $\begin{array}{l}\text { Mode of } \\
\text { use }\end{array}$ & Dosage & $\begin{array}{c}\text { Restrictions } \\
\text { of use }\end{array}$ \\
\hline $\begin{array}{c}\text { Informer } \\
\text { A }\end{array}$ & Leaves & $\begin{array}{c}\text { 3-4 leaves in } \\
1 / 4 \text { liter of fresh } \\
\text { water }\end{array}$ & Fresh & $\begin{array}{l}\text { Mix the leaves and } \\
\text { water in a blender for } \\
\text { a few seconds, then } \\
\text { filter. Shelf-life of } 1 \\
\text { hour }\end{array}$ & $\begin{array}{c}\text { Pain and } \\
\text { inflammation }\end{array}$ & Oral & $\begin{array}{c}\text { Adults only: } \\
1 \text { glass once } \\
\text { a day }\end{array}$ & $\begin{array}{c}\text { Not } \\
\text { mentioned }\end{array}$ \\
\hline
\end{tabular}

TABLE 6 - Poultice

\begin{tabular}{|c|c|c|c|c|c|c|c|c|}
\hline Informer & $\begin{array}{l}\text { Plant } \\
\text { part }\end{array}$ & $\begin{array}{l}\text { Plant/solvent } \\
\text { Proportion }\end{array}$ & $\begin{array}{l}\text { Plant } \\
\text { state }\end{array}$ & Preparation & $\begin{array}{c}\text { Claimed } \\
\text { medicinal use(s) }\end{array}$ & $\begin{array}{l}\text { Mode of } \\
\text { use }\end{array}$ & Dosage & $\begin{array}{c}\text { Restrictions } \\
\text { of use }\end{array}$ \\
\hline $\begin{array}{c}\text { Informer } \\
\text { A }\end{array}$ & $\begin{array}{l}\text { Entire } \\
\text { plant }\end{array}$ & $\begin{array}{c}\text { One leafy } \\
\text { branch of the } \\
\text { plant }\end{array}$ & Fresh & $\begin{array}{l}\text { Shred the plant } \\
\text { material and boil } \\
\text { in water for a few } \\
\text { minutes, then } \\
\text { mix the hot plant } \\
\text { material with } \\
\text { some clay and } \\
\text { apply as poultice }\end{array}$ & $\begin{array}{l}\text { Hepatitis and } \\
\text { cirrhosis }\end{array}$ & Topical & $\begin{array}{l}\text { Adults only: } \\
\text { apply the } \\
\text { poultice over } \\
\text { the inflamed } \\
\text { area for } 4 \\
\text { hours once } \\
\text { a dayObs. } \\
\text { Use during } 3 \\
\text { months }\end{array}$ & $\begin{array}{c}\text { Not } \\
\text { mentioned }\end{array}$ \\
\hline $\begin{array}{l}\text { Informer } \\
\text { C }\end{array}$ & $\begin{array}{l}\text { Entire } \\
\text { plant }\end{array}$ & $\begin{array}{l}\text { A handful of } \\
\text { plant }\end{array}$ & Fresh & $\begin{array}{l}\text { Cook the plant } \\
\text { material in olive } \\
\text { oil, let it cool } \\
\text { before using }\end{array}$ & Wounds & Topical & $\begin{array}{l}\text { Adults only: } \\
\text { apply the } \\
\text { poultice over } \\
\text { the wound } \\
\text { once a day }\end{array}$ & $\begin{array}{c}\text { Not } \\
\text { mentioned }\end{array}$ \\
\hline
\end{tabular}

TABLE 7. Syrup

\begin{tabular}{|c|c|c|c|c|c|c|c|c|}
\hline Informer & $\begin{array}{l}\text { Plant } \\
\text { part }\end{array}$ & $\begin{array}{c}\text { Plant/solvent } \\
\text { Proportion }\end{array}$ & $\begin{array}{l}\text { t Plant } \\
\text { state }\end{array}$ & Preparation & $\begin{array}{c}\text { Claimed } \\
\text { medicinal use(s) }\end{array}$ & $\begin{array}{l}\text { Mode } \\
\text { of use }\end{array}$ & Dosage & $\begin{array}{c}\text { Restrictions } \\
\text { of use }\end{array}$ \\
\hline $\begin{array}{l}\text { Informer } \\
\text { C }\end{array}$ & $\begin{array}{l}\text { Entire } \\
\text { plant }\end{array}$ & $\begin{array}{l}1 \text { cup of plant } \\
\text { material in } \\
2 \text { glasses of } \\
\text { water }\end{array}$ & Fresh & $\begin{array}{l}\text { In a stainless steel casserole add } 2 \\
\text { glasses of water and } 2 \text { cups of brown } \\
\text { sugar or honey, let boil for } 3 \text { minutes. } \\
\text { Then, add } 1 \text { cup of plant material and } \\
\text { boil it for one more minute covering the } \\
\text { casserole. Let it cool and then filter }\end{array}$ & $\begin{array}{l}\text { Allergic cough, } \\
\text { bronchitis, } \\
\text { pulmonary phlegm, } \\
\text { sore throat }\end{array}$ & Oral & $\begin{array}{l}\text { Adults only: } \\
1 \text { tbsp. } 3 \\
\text { times a day }\end{array}$ & $\begin{array}{c}\text { People } \\
\text { presenting } \\
\text { honey allergy }\end{array}$ \\
\hline
\end{tabular}

Rev. Bras. PI. Med., Botucatu, v.15, n.1, p.34-40, 2013. 
TABLE 8. Medicinal wine

\begin{tabular}{|c|c|c|c|c|c|c|c|c|}
\hline Informer & $\begin{array}{l}\text { Plant } \\
\text { part }\end{array}$ & $\begin{array}{l}\text { Plant/solvent } \\
\text { Proportion }\end{array}$ & $\begin{array}{l}\text { Plant } \\
\text { state }\end{array}$ & Preparation & $\begin{array}{c}\text { Claimed } \\
\text { medicinal use(s) }\end{array}$ & $\begin{array}{l}\text { Mode of } \\
\text { use }\end{array}$ & Dosage & $\begin{array}{l}\text { Restrictions } \\
\text { of use }\end{array}$ \\
\hline $\begin{array}{c}\text { Informer } \\
\text { C }\end{array}$ & $\begin{array}{l}\text { Entire } \\
\text { plant }\end{array}$ & $\begin{array}{c}1 \text { cup of plant } \\
\text { material in } 1 \\
\text { liter of red wine }\end{array}$ & Fresh & $\begin{array}{c}\text { Boil } 1 \text { liter of red wine in a } \\
\text { stainless steel casserole for } 5 \\
\text { minutes. Add } 1 \text { cup of brown } \\
\text { sugar or honey and then } 1 \\
\text { cup of plant material, mix it } \\
\text { until the sugar or honey has } \\
\text { dissolved. Then, boil it for } \\
\text { one more minute covering the } \\
\text { casserole. Let it cool and filter. } \\
\text { Store the preparation in a dark } \\
\text { glass }\end{array}$ & $\begin{array}{c}\text { Uterus infection, } \\
\text { vaginitis }\end{array}$ & Oral & $\begin{array}{l}\text { Adults only: } \\
1 \text { tbsp. of } \\
\text { medicinal } \\
\text { wine } \\
\text { dissolved in } 1 / 2 \\
\text { cup of water } 4 \\
\text { times a day }\end{array}$ & $\begin{array}{c}\text { People } \\
\text { presenting } \\
42 \text { honey allergy }\end{array}$ \\
\hline
\end{tabular}

Informer A reported using this preparation herself 4 hours a day during 3 months, associated with Bidens pilosa infusion to treat hepatitis $\mathrm{C}$, from which she supposedly recovered.

Preparation methods for syrup and therapeutic applications shown in Table 7 are in accordance with the guidelines in the literature (Martins, 2000).

Medicinal wine preparation methods and plant material/solvent proportion (Table 8) diverge from the methods described by Martins (2000).

\section{DISCUSSION}

Popular knowledge of medicinal plants is an important aspect of cultural heritage for a large number of communities and thus should be documented and conserved. Furthermore, such knowledge represents the basis for natural product research and can lead to drug discovery.

In this survey, some divergences in the uses of Bidens pilosa were found when comparing data from the informers' reports and data from the scientific and popular literature. Dosage and therapeutic indications, such as anti-inflammatory, anti-infective (urinary tract), anti-diabetic, anti-bronchitis, as well as to treat sore throat, stomach pain, rheumatic disease and muscular pain, are in accordance with the uses described in the popular literature. Some reported therapeutic indications for preparations of Bidens pilosa, such as uterus infection, vaginitis, cough and pain, seem devoid of popular validation, and precaution should be taken when using it for these purposes. Several studies have extensively investigated the phytochemical content of Bidens pilosa. The presence of flavonoids such as centaurein and centaureidin, and polyacetylenes such as 2-O-â-D-glucosyltrideca-11E-en-3,5,7,9-tetrayn1,2-diol, has been associated with antioxidant and anti-inflammatory effects (Pereira et al., 1999; Yang et al., 2006; Chang et al., 2007). Other biological activities have also been related to Bidens pilosa. The flavonoid quercetin-3,32 -dimethoxy-7-Orhamnoglucopyranose and the acetylene 1-phenyl1,3-diyn-5-en-7-ol-acetate could be responsible for the antimalarial activity of traditional preparation of Bidens pilosa (Brandão et al., 1997; Oliveira et al., 2004). In addition, polyacetylenes from Bidens pilosa var. radiata seem also to present anti-diabetic and anti-hyperglicemic effects (Hsu et al., 2008; Chien et al., 2009). Furthermore, antibacterial, antifungal, antioxidant (Chiang et al., 2004; Deba et al., 2007), antitumor (Kviecinski et al, 2008), antiulcer (Alvarez et al., 1999), vasorelaxant (Théophile et al., 2006) and immunomodulatory (Chiang et al, 2006; Chang et al., 2007) effects have been associated with Bidens pilosa compounds. Polyacetylenes and flavonoids are predominant in the phytochemistry of Bidens pilosa; these are also the most reported classes of compounds when turning to biological activities, and these findings can corroborate a number of therapeutic applications indicated by the Health Pastoral informers in the present survey.

\section{ACKNOWLEDGEMENTS}

The authors express their thanks to Universidade do Extremo Sul Catarinense-UNESC and CNPq for financial support.

\section{REFERENCES}

AMOROZO, M.C. DE M. A abordagem etnobotânica na pesquisa de plantas medicinais. In: DI STASI, L.C. Plantas medicinais: arte e ciência um guia de estudo interdisciplinar. São Paulo: UNESP, 1996. p.47-68.

ALVAREZ, A.; POMAR, F.; SEVILLA, M.A.; MONTERO, J. Gastric antisecretory and antiulcer activities of an ethanolic extract of Bidens pilosa L. var. radiata Schult. Bip. Journal of Ethnopharmacology, v.67, n.3, p.333-40, 1999.

BRANDÃO, M.G.L.; KRETTLI, A.U.; SOARES, L.S.R.; NERY, C.G.C.; MARINUZZI, H.C.. Antimalarial activity of extracts and fractions from Bidens pilosa and other Bidens species (Asteraceae) correlated with the presence of acetylene and flavonoid compounds. Journal of Ethnopharmacology, v.57, p.131-38, 1997.

CHANG, S.L.; CHIANG, Y.M.; CHANG, C.L.T.; YEH, H.H.; SHYUR, L.F.; KUO, Y.H.; WU, T.K.; YANG, W.C. Flavonoids, centaurein and centaureidin, from Bidens pilosa, stimulate IFN-ã expression. Journal of Ethnopharmacology, v.112, n.2, p.232-36, 2007.

CHIANG, Y.M.; CHUANG, D.Y.; WANG, S.Y.; KUO,

Rev. Bras. PI. Med., Botucatu, v.15, n.1, p.34-40, 2013. 
Y.H.; TSAI, P.W.; SHYUR, L.F. Metabolite profiling and chemopreventive bioactivity of plant extracts from Bidens pilosa. Journal of Ethnopharmacology, v.95, p.409-19, 2004.

CHIANG, Y.M.; CHANG, C.L.T.; CHANG, S.L.; YANG, W.C.; SHYUR, L.F. Cytopiloyne, a novel polyacetylenic glucoside from Bidens pilosa, functions as a $\mathrm{T}$ helper cell modulator. Journal of Ethnopharmacology, v.110, n.3, p.532-38, 2006.

CHIEN, S.C.; YOUNG, P.H.; HSU, Y.J.; CHEN, C.H.; TIEN Y.J.; SHIU, S.Y.; LI, T.H.; YANG, C.W.; MARIMUTHU, P.; TSAI, L.F.L.; YANG, W.C. Anti-diabetic properties of three common Bidens pilosa variants in Taiwan. Phytochemistry, v.70, p.1246-254, 2009.

CORRÊA, M.P. Dicionário das plantas úteis do Brasil e das exóticas cultivada. Rio de Janeiro: Ministério de agricultura, 1984. 777p.

CORREAA, A.D.; BATISTA, R.S.; QUINTAS ; L.E.M. Plantas medicinais: do cultivo à terapêutica. 2.ed. Petrópolis: Vozes, 1998. 247p.

CORREAA, A.D.; BATISTA, R.S.; QUINTAS, L.E.M. Plantas medicinais: do cultivo à terapêutica. 6.ed. Petrópolis: Vozes, 2003. 247p.

COSTA, A.F. Farmacognosia. 2.ed. Lisboa: Fundação Calouste Gulbenkian, 1972. 372p.

DEBA, F.; XUAN, T.D.; YASUDA, M.; TAWATA, S. Chemical composition and antioxidant, antibacterial and antifungal activities of the essential oils from Bidens pilosa Linn. var. radiata. Food Control, v.19, n.4, p.346-52, 2007.

DEHAVEN, M.J.; HUNTER, I.B.; WILDER, L.; WALTON, J.W.; BERRY, J. Health programs in Faith-Based Organizations : Are they effective? American Journal of Public Health, v.94, n.6, p.1030-036, 2004.

DI STASI, L.C. Plantas medicinais: arte e ciência um guia de estudo interdisciplinar. São Paulo: UNESP, 1996. 230p. ELISABETSKY, E.; COSTA-CAMPOS, L. Medicinal Plant Genetic Resources and International Cooperation: The Brazilian perspective. Journal of Ethnopharmacology, v.51, p.111-20, 1996.

ELISABETSKY, E. From Indigenous Disease Concepts to Laboratory Working Hypothesis: The case of nerve tonics from the Brazilian Amazon. Stockholm (Sweden). International Foundation for Science- Provisional Report Series, v.19, 1987.

ELISABETSKY, E. New directions in Ethnopharmacology. Journal of Ethnobiology, v.6, n.1, p.121-28, 1986.

BRASIL. Farmacopéia brasileira. 2.ed. São Paulo: Siqueira, 1959. 1265p.

FRANCO, I.J.; FONTANA, V.L. Ervas e plantas: a medicina dos simples. 9.ed., Erechim: Livraria Vida, 2004. 208p.

HSU, Y.J.; LEE, T.H.; CHANG, C.L.T.; HUANG, Y.T.; YANG, W.C. Anti-hyperglycemic effects and mechanism of Bidens pilosa water extract. Journal of Ethnopharmacology, v.122, p.379-83, 2008.

IBGE, Instituto Brasileiro de Geografia e Estatística. Censo Demográfico 2000 - Tabela 2094 População residente por cor ou raça e religião. Brazil, 2000. Available at: http://www.sidra.ibge.gov.br/cd/cd2000cgp.asp?o=11\&i=P. Accessed on: April.2010

KVIECINSKI, M.R.; FELIPE, K.B.; SCHOENFELDER, T.; DE LEMOS WIESE, L.P.; ROSSI, M.H.; GONÇALEZ, E.; FELICIO, J.D.; FILHO, D.W.; PEDROSA, R.C. Study of the antitumor potential of Bidens pilosa (Asteraceae) used in
Brazilian folk medicine. Journal of Ethnopharmacology, v.117, n.1, p.69-75, 2008.

MACIEL, M.A.M.; PINTO, A.C.; VEIGA, J.R.; GRYNBERG, N.F.; ECHEVARRIA, A. Plantas medicinais: a necessidade de estudos multidisciplinares. Química Nova, v.25, n.3, p.429-38, 2002.

MARTINS, E.R.; CASTRO, D.M. de; CASTELLANI, D.C.; DIAS, J.E. Plantas medicinais. Viçosa: UFV, 2000. 220p. MURRAY, L.R.; GARCIA, J.; MUÑOZ-LABOY, M.; PARKER, R.G. Strange bedfellows: The Catholic Church and Brazilian National AIDS Program in the response of HIVIAIDS in Brazil. Social Science \& Medicine, v.72, p.945-52, 2011. OLIVEIRA, F.Q.; ANDRADE-NETO, V.; KRETTLI, A.U.; BRANDÃO, M.G.L. New evidences of antimalarial activity of Bidens pilosa roots extract correlated with polyacetylene and flavonoids. Journal of Ethnopharmacology, v.93, p.39-42, 2004.

PEREIRA, R.L.C.P.; IBRAHIM, T.; LUCCHETTI, L.; SILVA, A.J.R.; MORAES, V.L.G. Immunosuppressive and anti-inflammatory effects of methanolic extract and the polyacetylene isolated from Bidens pilosa L. Immunopharmacology, v.43, p.31-37, 1999.

PHILLIPSON, J.D. Phytochemistry and pharmacognosy. Phytochemistry, v.68, p.2960-72, 2007.

PRISTA, L.V.N.; ALVES, A.C.; MORGADO, R. Técnica farmacêutica e farmácia galénica. 3.ed. Lisboa: Fundação Calouste Gulbenkian, 1990. 518p.

PRISTA, L.V.N.; ALVES, A.C.; MORGADO, R. Técnica farmacêutica e farmácia galénica. 4.ed. Lisboa: Fundação Calouste Gulbenkian, 1991. 518p.

RATES, S.M.K. Plants as source of drugs. Toxicon, v.39, p.603-13, 2000.

SARG, T.M.; ATEYA, A.M.; FARRAG, N.M.; ABBAS, F.A. Constituents and biological activity of Bidens pilosa L. grown in Egypt. Acta Pharmaceutica Hungaria, v.61, n.6, p.317-23, 1991.

SILVA JUNIOR, A.A. Essentia Herba: Plantas Bioativas. 2.ed. Florianópolis: EPAGRI, 2006. 633p.

SILVA, F.L.; FISCHER, D.C.H.; TAVARES, J.F.; SILVA, M.S.; ATHAYDE-FILHO, P.F.; BARBOSA-FILHO, J.M. Compilation of secondary metabolites from Bidens pilosa L. Molecules, v.16, p.1070-102, 2011.

SIMÕES, C.M.O. Plantas da medicina popular no Rio Grande do Sul. 5.ed. Porto Alegre: UFGRS, 1989. 173p. TAN, P.V.; DIMO, T.; DONGO, E. Effects of methanol, cyclohexane and methylene chloride extracts of Bidens pilosa on various gastric ulcer models in rats. Journal of Ethnopharmacology, v.73, p.415-21, 2000.

THÉOPHILE, D.; TÉLESPHORE, N.B.; PAUL, T.V.; LAURENT, F.; SILVERE, R.V.; LOUIS, T.P.; CROS, G. Vascular smooth muscle relaxant properties of the leaf methanol extract of Bidens pilosa Linn (Asteraceae). Pharmacologyonline, v.3, p.180-91, 2006.

VALDÉS, H.A.L.; REGO, H.P.L. Bidens pilosa Linné. Revista Cubana de Plantas Medicinais, v.1, p.28-33, 2001.

VILEGAS, W.; CARDOSO, C.A.L. Controle químico de qualidade de fitoterápicos e plantas medicinais. In: YUNES, R.A.; CECHINEL FILHO, V. Química de produtos naturais, novos fármacos e a moderna farmacognosia. Itajaí: UNIVALI, 2007, p.155-82.

XORGE, A.D. Métodos de Investigação Fitoquímica. México: Editorial Limusa, 1973. 281p. 